\title{
Investigating Targets of Avian Habitat Management to Eliminate an Ecological Trap
}

\section{Recherche de cibles d'aménagement d'habitat aviaire pour éliminer le piège écologique}

\author{
Bruce A. Robertson $^{1}$
}

\begin{abstract}
Ecological traps are attractive population sinks created when anthropogenic habitat alteration inadvertently creates a mismatch between the attractiveness of a habitat based upon its settlement cues, and its current value for survival or reproduction. Traps represent a new threat to the conservation of native species, yet little attention has been given to developing practical approaches to eliminating them. In the northern Rocky Mountains of Montana, Olive-sided Flycatchers (Contopus cooperi) prefer to settle in patches of selectively harvested forest versus burned forest despite the lower reproductive success and higher nest predation risk associated with the former habitat. I investigated characteristics of preferred perch sites for this species and how these preferences varied between habitats and sexes. I then built on previous research to develop a range of management prescriptions for reducing the attractiveness of selectively harvested forest, thereby disarming the ecological trap. Female flycatchers preferred to forage from shorter perch trees than males, and females' perches were shorter than other available perch trees. Both sexes preferred standing dead perch trees (snags) and these preferences were most obvious in harvested forest where snags are rarer. Because previous research shows that snag density is linked to habitat preference and spruce/fir trees are preferred nest substrate, my results suggest these two habitat components are focal habitat selection cues. I suggest alternative and complementary strategies for eliminating the ecological trap for Olive-sided Flycatchers including: (1) reduced retention and creation of snags, (2) avoiding selective harvest in spruce, fir, and larch stands, (3) avoiding retention of these tree species, and (4) selecting only even-aged canopy height trees for retention so as to reduce perch availability for female flycatchers. Because these strategies also have potential to negatively impact habitat suitability for other forest species or even create new ecological traps, we urge caution in the application of our management recommendations.
\end{abstract}

RÉSUMÉ. Impasses attrayantes pour les populations, les pièges écologiques sont créés par inadvertance lorsque des modifications d'habitat d'origine humaine amènent une inéquation entre l'attrait d'un milieu fondé sur ses indices apparents de qualité et sa valeur véritable pour la survie ou la reproduction. Ces pièges représentent une nouvelle menace pour la conservation des espèces indigènes, mais peu d'attention a été accordée jusqu'à maintenant pour trouver des approches pratiques destinées à les éliminer. Dans les Rocheuses au Montana, le Moucherolle à côtés olive (Contopus cooperi) préfère s'établir dans les îlots de coupes de jardinage plutôt que dans les brûlis malgré le succès de reproduction plus faible et le risque de prédation sur les nids plus élevés dans les premiers. Les caractéristiques des perchoirs préférés pour cette espèce et leurs variations ont été examinées selon l'habitat et le sexe. À partir de données d'études antérieures, un ensemble de prescriptions d'aménagement visant à réduire l'attrait des peuplements jardinés a été établi, désamorçant ainsi le piège écologique. Les moucherolles femelles préféraient chercher de la nourriture à partir d'arbres plus courts que ceux utilisés par les mâles, et les arbres utilisés par les femelles étaient plus courts que les autres arbres perchoirs disponibles. Mâles et femelles préféraient des arbres morts encore debout (chicots) comme perchoirs et cette préférence s'observait davantage dans les peuplements jardinés, où les chicots sont plus rares que dans les brûlis. Étant donné que des études antérieures ont montré que la densité des chicots était liée à la préférence d'habitat et que les épinettes et les sapins étaient les arbres de nidification préférés, les résultats de la présente étude laissent entendre que ces deux composantes sont déterminantes dans la sélection de l'habitat. Des stratégies de remplacement complémentaires ont été élaborées afin d'éliminer le piège écologique chez le Moucherolle à côtés olive : 1) réduire le maintien des chicots et leur création; 2) éviter le jardinage dans les peuplements d'épinettes, de sapins et de mélèzes; 3) éviter le maintien de ces espèces arboricoles; et 4) sélectionner seulement les peuplements équiennes d'arbres de même hauteur en vue de la rétention afin de

${ }^{1}$ Bard College

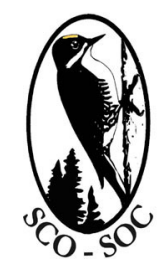

Sponsored by the Society of Canadian Ornithologists and Bird Studies Canada

Parrainée par la Société des ornithologistes du Canada et Etudes d'oiseaux Canada

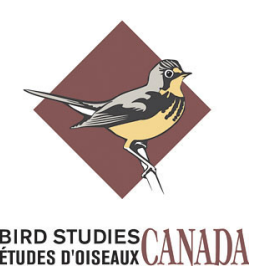


réduire la disponibilité d'arbres perchoirs pour les femelles. Puisque ces stratégies ont le potentiel d'avoir un effet négatif sur la qualité de l'habitat d'autres espèces forestières, ou même encore de créer de nouveaux pièges écologiques, il est impératif de redoubler de précautions dans l'application des recommandations d'aménagement ici proposées.

Key Words: behavioral management; disturbance-dependent; evolutionary trap; habitat preference; selective logging; wildfire

\section{INTRODUCTION}

Ecological traps are scenarios in which rapid anthropogenically driven environmental change triggers animals to prefer poorquality habitat to alternative habitat that confers higher survival or reproductive success (Dwerychuk and Boag 1972, Schlaepfer et al. 2002). Traps occur because animals use indirect cues to assess the ultimate value of potential habitats during settlement, but these cues can be manipulated independently of the fitness conditions to which they have been correlated over evolutionary time (Robertson and Hutto 2006). If human activity inadvertently decouples those behavioral cues from their fitness correlates, the result can be the creation of attractive population sinks capable of rapidly driving populations to extinction (Kokko and Sutherland 2001, Fletcher et al. 2012).

Ecological traps for bird species have been created as an inadvertent consequence of exotic species introductions (Rodewald et al. 2011), agriculture (Powell et al. 2010), and even activities whose goal is ecological restoration (Robertson and Hutto 2007, Hawlena et al. 2010). In general, researchers have focused largely on documenting the existence of traps and have dedicated relatively little attention to developing practical methods to eliminate or prevent them (but see Horvath et al. 2009). One method should involve reducing the attractiveness of trap habitat below that of alternative and higher quality habitat types (Robertson and Hutto 2006). The specific method by which this can be accomplished will depend upon the habitat selection cues used by the focal organism, the putative anthropogenic impact at fault, and whether cues, habitat quality, or both are targeted for management (Schlaepfer et al. 2002, Robertson and Hutto 2006). Practically speaking, this approach involves identifying the broadest possible library of habitat components used as settlement cues by a trapped organism, and then developing a range of potential management strategies for reducing habitat attractiveness through alteration of those cue sets. A breadth of strategic approaches is necessary because some options may be prohibitively expensive, logistically infeasible, or incompatible with human activity. However, no systematic attempt to develop options for habitat management focusing on trap prevention and elimination has yet been made.

The goal of this study is to first investigate habitat components potentially linked to habitat preference in a bird species caught in an ecological trap, and then to examine how this knowledge can be put to practical use in eliminating that trap. In the Rocky Mountains, timber management has increasingly embraced the use of selective harvesting techniques aimed at better mimicking the habitat structure and composition typical after the passage of wildfire, the dominant natural disturbance in the region. Olive-sided Flycatchers (Contopus cooperi) are insectivorous passerine birds. Studies throughout its western breeding range have found it to be relatively abundant in selectively harvested forests (reviewed in Altman and Sallabanks 2000) and in its dominant natural habitat in the region: forests impacted by the passage of moderate to severe wildfire (Hutto 1995, Hutto and Young 1999). In northwestern Montana, Robertson and Hutto (2007) found that this species prefers to settle in selectively logged forests over burned habitat, but relative preference for these habitats has not been tested at other locations. Potential nest predators are more abundant in harvested forest patches which likely accounts for a reproductive success below that of individuals settling in burned forest and leading to the creation of an ecological trap for this species (Robertson and Hutto 2007).

Robertson and Hutto (2007) found that the abundance of standing dead trees (snags) and spruce and fir species preferred as nesting substrates were positively linked to territory preferences. Because Olive-sided Flycatchers prey exclusively on aerial arthropods captured mid-air from elevated perches (Altman and Sallabanks 2000), the availability of suitable perches should also be of significant importance in the selection of a breeding territory. I focused on investigating characteristics of preferred foraging and song perches of Olive-sided Flycatchers and examined how preferences vary by sex and between ecological trap (selectively harvested) and burned habitat types.

\section{METHODS}

\section{Study site}

I conducted this study at the two locations used by Robertson and Hutto (2007) to demonstrate the existence of an ecological trap for Olive-sided Flycatchers. This study was conducted in 2002 and concurrently with that study. The first study site was the $\sim 4000$ ha Big Creek Basin within the intersection of the Flathead National Forest and the Moose Fire that burned the eastern portion of that forest in 2001. The majority of the study area burned at high severity, but burn severity was heterogeneous throughout. The minimum distance from all study sites to the burn perimeter was $>1.0 \mathrm{~km}$. The second, similarly sized area was located $14 \mathrm{~km}$ north of Whitefish, Montana and managed by the Plum Creek Timber Company for timber production. It consisted of patches of thinned forest interspersed with patches unharvested for $>40$ years. Selective 
Table 1. Characteristics of trees used as perches by Olive-sided Flycatchers (Contopus cooperi) in northwestern Montana as a function of habitat type (burned vs. selectively harvested forest) and whether perching individuals were (1) singing males, (2) foraging males, or (3) foraging females. Wald $\chi^{2}$ values and their associated P-values are derived from generalized estimating equation models. Parameter estimate are given with their standard errors. Marginal mean values for perch tree height (meters) and the distance below the tree top at which a flycatcher perched (meters) are listed. The marginal probabilities (p) of a perch tree being (1) partially alive vs. entirely dead (a snag) and (2) having a minimum $0.5 \mathrm{~m}$ dead portion at its apex are given. Sex/ foraging-group specific values for a focal perch characteristic that share a superscript letter are not significantly different.

\begin{tabular}{|c|c|c|c|c|c|c|c|c|c|c|}
\hline \multirow[b]{2}{*}{ Perch characteristic } & \multicolumn{3}{|c|}{ Harvested Forest } & \multicolumn{3}{|c|}{ Burned Forest } & \multicolumn{2}{|c|}{ Habitat } & \multicolumn{2}{|c|}{ Sex/song } \\
\hline & Singing males & Foraging males & Females & Singing males & Foraging males & Females & $\chi^{2}$ & $P$ & $\chi^{2}$ & $P$ \\
\hline Tree height (m) & $18.3^{\mathrm{a}} \pm 5.6$ & $14.7^{\mathrm{a}} \pm 1.5$ & $9.5^{\mathrm{b}} \pm 1.2$ & $16.7^{\mathrm{a}} \pm 1.6$ & $15.2^{\mathrm{a}} \pm 0.8$ & $8.7^{\mathrm{b}} \pm 0.6$ & 0.8 & 0.37 & 41.5 & $<0.001$ \\
\hline $\begin{array}{l}\text { Distance from tree } \\
\text { top (m) }\end{array}$ & $0.42^{\mathrm{a}} \pm 0.11$ & $1.31^{\mathrm{b}} \pm 0.12$ & $1.22^{\mathrm{b}} \pm 0.11$ & $0.34^{\mathrm{a}} \pm 0.04$ & $1.19^{b} \pm 0.20$ & $1.07^{\mathrm{b}} \pm 0.14$ & 0.4 & 0.51 & 65.6 & $<0.001$ \\
\hline Live perch tree (p) & $0.39^{\mathrm{a}} \pm 0.06$ & $0.42^{\mathrm{a}} \pm 0.06$ & $0.30^{\mathrm{a}} \pm 0.07$ & $0.21^{\mathrm{b}} \pm 0.04$ & $0.22^{\mathrm{b}} \pm 0.05$ & $0.15^{\mathrm{b}} \pm 0.04$ & 7.6 & 0.01 & 2.8 & 0.25 \\
\hline Live-topped tree (p) & $0.12^{\mathrm{a}} \pm 0.04$ & $0.09^{\mathrm{a}} \pm 0.03$ & $0.05^{\mathrm{a}} \pm 0.02$ & $0.11^{\mathrm{a}} \pm 0.03$ & $0.08^{\mathrm{a}} \pm 0.03$ & $0.04^{\mathrm{a}} \pm 0.02$ & 0.2 & 0.64 & 4.0 & 0.14 \\
\hline
\end{tabular}

harvest techniques applied to the site were most commonly seed-tree cuts occurring within the previous 5-10 years. Harvested and burned sites were of similar age-class, elevation (1490-1646m), and latitude. Study areas were sites dominated by mixed-conifer forest stands of ponderosa pine (Pinus ponderosa), Douglas-fir (Pseudotsuga menziesii), western larch (Larix occidentalis), lodgepole pine (Pinus contorta), subalpine fir (Abies lasiocarpa), and Engelmann spruce (Picea engelmannii).

\section{Perch characterization}

Olive-sided Flycatchers hunt aerial arthropods by hawking from an elevated perch to which they commonly return after both successful and failed attacks (Altman and Sallabanks 2000). I identified characteristics of perches associated with territorial pairs of male and female Olive-sided Flycatchers. Robertson and Hutto (2007) conducted daily systematic aural surveys of the study areas for flycatchers during the settlement period, revisited locations of all territorial males weekly to search for nests, visited nest sites every four days to assess nest fate, and used standard spot-mapping techniques to characterize the spatial extent of territories. During visits to each territory (Robertson and Hutto 2007), I collected data about the characteristics of trees upon which individual flycatchers perched to sing or forage. I first located individuals by sight or sound. Because only males sing (Altman and Sallabanks 2000), I assumed that individuals giving territorial songs were males. Individuals were identified as females if they were seen either (1) incubating, or (2) feeding young, or were otherwise present within $75 \mathrm{~m}$ of an active nest site, were also in association with an individual already established to be a male, and were not attacked by that male. Because Olivesided Flycatchers are extremely aggressive, vigorously attacking male territorial intruders (Altman and Sallabanks 2000; Robertson unpublished data), failure to elicit attack by the territorial male is a robust indicator that an individual is female.

Upon locating a perched flycatcher I maintained a minimum distance of $50 \mathrm{~m}$ from the tree upon which it was perched and determined whether the individual was actively foraging, was engaged in territorial song, or some other activity, e.g., loafing, scanning for predators. Individuals were considered to be foraging if they made $\geq 1$ hawking maneuver from a focal perch. I recorded the following characteristics of each foraging or song perch: (1) the height of the perch tree, (2) the height of the focal flycatcher in relation to total tree height, (3) species of the perch tree, (4) whether the tree appeared to be entirely dead or partially alive, and (5) whether the top $0.5-3.0 \mathrm{~m}$ was devoid of foliage ('dead topped') or had at least some green foliage ('live-topped'). I estimated tree heights by triangulation using a clinometer and measuring tape.

For each territory mapped by Robertson and Hutto (2007), I located a paired $36 \mathrm{~m}$-radius plot outside known territorial boundaries, but within $100 \mathrm{~m}$ of the mapped territorial boundary of the focal individual. I characterized each tree in this patch according to the five perch site criteria above. For each territory, each perch site was paired with a randomly selected tree from the paired, but unused, plot as a representative of available perch trees in the area at large. Territories of male Olive-sided Flycatchers were widely separated in space and abutted (mapped boundaries were < $100 \mathrm{~m}$ from each other) in only one instance (Robertson and Hutto 2007). In this case I avoided sampling perches from along the boundary of potential overlap.

\section{Statistical analyses}

I used generalized estimating equation (GEE) models to test for differences in the characteristics of perch sites used by (1) singing males, (2) foraging males, and (3) foraging females. I used a negative binomial distribution with log link function to fit data. I used GEE models with a binary logistic link function to test for differences in perch characteristics between burn and harvested forest and between the characteristics of perches vs. randomly selected trees. A territory identifier was included as a random factor in both groups of analyses to control for any within-subject correlations. I used multinomial logistic regression to test for sex- and habitat-related differences in the frequency of tree species used as perches. 
Table 2. Comparison of characteristics of trees used as perches used by Olive-sided Flycatchers (Contopus cooperi) in northwestern Montana with randomly selected trees. Used perch trees are compared with randomly selected trees located outside of known breeding territories and as a function of habitat type (burned vs. selectively harvested forest). Each comparison is made separately for males ( $\mathrm{M}$, singing and foraging combined) and females $(\mathrm{F})$. Wald $\chi^{2}$ values and their associated $\mathrm{P}$-values are derived from generalized estimating equation models. Marginal mean values are given for perch tree height in meters. The marginal probabilities (p) of a perch tree being (1) partially alive vs. entirely dead (a snag) and (2) having a minimum $0.5 \mathrm{~m}$ dead portion at its apex are given. Used/unused values for a focal sex and perch characteristic that share a superscript letter are not significantly different. Parameter estimates are given with their standard errors.

\begin{tabular}{|c|c|c|c|c|c|c|c|c|c|c|c|}
\hline \multirow[b]{2}{*}{ Perch characteristic } & \multirow[b]{2}{*}{ Sex } & \multicolumn{2}{|c|}{ Burned } & \multicolumn{2}{|c|}{ Harvested } & \multicolumn{2}{|c|}{ Used vs. random } & \multicolumn{2}{|c|}{ Habitat } & \multicolumn{2}{|c|}{ Interaction } \\
\hline & & Used & Random & Used & Random & $\chi^{2}$ & $P$ & $\chi^{2}$ & $P$ & $\chi^{2}$ & $P$ \\
\hline \multirow[t]{2}{*}{ Perch tree height $(\mathrm{m})$} & M & $17.6^{\mathrm{a}} \pm 1.5$ & $16.5^{\mathrm{a}} \pm 1.1$ & $15.0^{\mathrm{a}} \pm 0.7$ & $17.0^{\mathrm{a}} \pm 0.5$ & 1.7 & 0.19 & 1.5 & 0.22 & & \\
\hline & $\mathrm{F}$ & $10.0^{\mathrm{a}} \pm 1.7$ & $15.3^{\mathrm{b}} \pm 0.6$ & $8.7^{\mathrm{a}} \pm 0.7$ & $17.5^{\mathrm{b}} \pm 0.5$ & 46.7 & $<0.001$ & 0.1 & 0.85 & & \\
\hline \multirow[t]{2}{*}{ Live perch tree (p) } & M & $0.24^{\mathrm{a}} \pm 0.04$ & $0.19^{\mathrm{a}} \pm 0.08$ & $0.40^{\mathrm{b}} \pm 0.05$ & $0.88^{\mathrm{c}} \pm 0.03$ & 8.9 & 0.003 & 57.0 & $<0.001$ & 15.4 & $<0.001$ \\
\hline & $\mathrm{F}$ & $0.02^{\mathrm{a}} \pm 0.02$ & $0.14^{\mathrm{a}} \pm 0.09$ & $0.37^{\mathrm{b}} \pm 0.08$ & $0.82^{\mathrm{c}} \pm 0.05$ & 20.0 & $<0.001$ & 15.8 & $<0.001$ & 14.2 & $<0.001$ \\
\hline \multirow[t]{2}{*}{ Live-topped tree (p) } & M & $0.11^{\mathrm{a}} \pm 0.03$ & $0.19^{\mathrm{a}} \pm 0.08$ & $0.10^{\mathrm{b}} \pm 0.02$ & $0.79^{c} \pm 0.04$ & 18.7 & $<0.001$ & 25.4 & $<0.001$ & 16.4 & $<0.001$ \\
\hline & $\mathrm{F}$ & $0.04^{\mathrm{a}} \pm 0.03$ & $0.03^{\mathrm{a}} \pm 0.03$ & $0.04^{\mathrm{a}} \pm 0.02$ & $0.80^{\mathrm{b}} \pm 0.06$ & 47.1 & $<0.001$ & 14.0 & $<0.001$ & 21.3 & $<0.001$ \\
\hline
\end{tabular}

Model outputs associated with continuous variables are presented as marginal means. Model outputs associated with dichotomous variables are presented in the form of marginal probabilities. The latter statistics represent the effect a change in the used vs. random status of a tree will have on the probability that a perch tree is living vs. dead, or live- vs. deadtopped. All analyses were conducted using SPSS version 19.0 (SPSS 2011).

\section{RESULTS}

I characterized a total of 381 perches from 34 territories selected by 27 female and 33 male Olive-sided Flycatchers. I found no differences in the height of perches selected by flycatchers in burned vs. selectively harvested habitat types. However, females selected perch trees $(x=9.5 \mathrm{~m})$ that were, on average, $55 \%$ shorter than those selected by foraging males $(\mathrm{x}=14.7 \mathrm{~m})$ and $115 \%$ shorter than perches from which males chose to sing ( $\mathrm{x}=18.3 \mathrm{~m}$; Table 1$)$. The marginal probability of selecting live trees as perches did not differ among singing males, foraging males, or foraging females, but was significantly higher for individuals inhabiting selectively harvested $(x=64 \%)$ compared with burned forests $(x=17 \%$; Table 1). The marginal probability of using live-topped trees over dead-topped trees was unrelated to habitat type or sex/ behavior group.

Female flycatchers preferred perch trees that were significantly shorter than available trees in both habitat types (Table 2). Male perch height (foraging and singing, combined) was similar to that of available trees regardless of habitat type. Both male and female flycatchers showed a strong preference for selecting standing dead and dead-topped trees as perches in selectively harvested forest, but not in burned forest (Table 2 ). This is indicated by the lower marginal probabilities of a tree being alive or live-topped. Tree species most frequently chosen as perches were Douglas-fir $(25.9 \%)$, western larch
(24.1\%), subalpine fir $(18.3 \%)$ and paper birch (Betula papyrifera; $10.7 \%$ ), across both habitats. Collectively, other tree species, e.g., Populus trichocarpa, Pinus contorta, and Picea engelmannii comprised the remaining $21 \%$ of perch observations and were combined into a single category ('other') for the purpose of analysis.

The overall model chi-square for the multinomial logistic regression modeling tree species as a function of habitat and perches vs. available trees was significant $\left(\chi^{2}=247.0, \mathrm{df}=10\right.$, $P<0.001)$, and indicated the model with habitat type was an improvement over the intercept-only model. Maximum likelihood tests indicated that tree species composition differed between habitat types $\left(\chi^{2}=132.0, \mathrm{df}=5, P<0.001\right)$ and that species composition of perch trees differed from unused, but available options $\left(\chi^{2}=145.4\right.$, df $\left.=5, P<0.001\right)$. Douglas-fir, western larch, and other tree species were more likely to be found in the selectively harvested habitat than the burned habitat (all odds ratios $>4.42$, all $P<0.001$ ), whereas subalpine fir and paper birch exhibited the opposite pattern (both odds ratios $>13.8$, both $P<0.001$ ). All four of the most common perch tree species were used out of proportion to their general availability outside of territories (all odds ratios $>4.1$, all $P<0.001$ ). Because preliminary tests found no significant difference in the tree species used by male and female flycatchers, the variable sex was not included in the final model.

\section{DISCUSSION}

I found sex-and habitat-specific variation in the characteristics of perches preferred by Olive-sided Flycatchers. Female flycatchers preferred to forage from shorter trees than did males. Both males and females preferred to perch, on average, approximately $0.4 \mathrm{~m}$ below the apex of the tree when foraging whereas males perched closer to the apex of a tree when singing than when foraging. There were no differences 
between the sexes in their tendency to use snags vs. live trees or live-trees with dead tops.

Males used perches of a similar height to available trees in both burned and selectively harvested forest, whereas females showed a tendency to select trees that were shorter than average in both habitat types. Both sexes were more likely to select snags and dead-topped trees over live and live-topped trees only in selectively harvested habitat (Table 2) where snags and dead-topped trees were rarer (also see Robertson and Hutto 2007). Intersexual differences in habitat use occur in other passerine species and commonly involve the spatial partitioning of foraging substrates (e.g., Aho et al. 1997, Pechacek 2006, Randler et al. 2010). This partitioning is thought to result either from sexual selection for dimorphism that favors sex-specific foraging strategies, intersexual competition for food, or as a byproduct of the different reproductive roles of males vs. females (reviewed by Hedrick and Temeles 1989).

At my study sites, subalpine fir, Engelmann spruce, and western larch were preferred nest-site substrates for Olivesided Flycatchers and are more abundant in flycatcher territories than in surrounding forest (Robertson and Hutto 2007). Spruces and true firs are the most common nest substrates throughout the breeding range of this species, probably because of the flat, dense, and rigid substrate they provide (Altman and Sallabanks 2000). Results from this study illustrate that these tree species, with the addition of paper birch and Douglas-fir, are also preferred substrates from which to initiate foraging attacks for both sexes. This provides an additional explanation for why these trees play a role in territory selection by males.

There are several mechanisms by which ecological traps are caused (Schlaepfer et al. 2002, Robertson and Hutto 2006). In each, human activity increases the attractiveness of a habitat relative to other available options, reduces its relative suitability for survival or reproduction, or both. As a corollary, options for eliminating ecological traps created by human activity should include (1) reducing the attractiveness of trap habitats to organisms, (2) increasing the suitability of trap habitat for survival and reproduction, or (3) both.

Definitive evidence for the mechanism(s) responsible for reduced Olive-sided Flycatcher reproductive success in selectively harvested stands at these study sites is lacking. Roughly three times more individuals of common predators including red squirrel (Tamiasciurus hudsonicus), Gray Jay (Perisoreus canadensis), and Common Raven (Corvus corax) occurred in harvested vs. early post-fire stands (Robertson and Hutto 2007), suggesting that birds nesting in harvested stands are subject to increased nest predation. If this is true, increasing the suitability of trap habitat would require management to reduce the abundance of these native and relatively common nest predators, which would be logistically difficult and, very likely, prohibitively expensive. Moreover, heightened availability of aerial arthropod prey in harvested forest (Meehan and George 2003) has been suggested as a possible cue attracting flycatchers into trap habitat (Robertson and Hutto 2007), but reducing aerial arthropod abundance is similarly beyond the practical tools of forest management. Instead, preventing the creation of additional ecological traps for this species will likely best be accomplished through silvicultural management approaches that reduce the attractiveness of trap habitat to settling flycatchers.

Results of this and previous research suggest several management options to eliminate the ecological trap for this species. Previous studies have documented positive associations between Olive-sided Flycatcher habitat use and snag density at the territory scale (Rosenberg and Raphael 1986, Wright 1997, Robertson and Hutto 2007). Results of this study illustrate that snags are preferred perches that are heavily used in selectively harvested forests where they are generally rare. This result adds emphasis to the importance of snag retention in attracting flycatchers to thinned forest patches that act as ecological traps and suggests that reducing retention and creation of snags in selective timber harvest should accomplish a reduction in habitat attractiveness by flycatchers.

My results also further highlight the importance of spruce, true fir, and larch species in enhancing the attractiveness of harvested forest patches to settling males. In additional to acting as preferred nesting substrates (Robertson and Hutto 2007) these tree species also appear to be preferred structures from which to forage, elevating their importance as key habitat features for this species. Selective harvesting that opens up dense forest canopies making them more suitable to flycatchers (Altman and Sallabanks 2000) can be avoided in spruce/true fir/larch stands altogether. Alternatively, selective harvest in these stands can target retention toward tree species less preferred by Olive-sided Flycatchers.

The observed intersexual differences in perch tree height preferences suggest a third avenue of management. Harvesting techniques can target the retention of canopy-height trees only, favoring removal of subcanopy trees favored by female flycatchers. Indeed Olive-sided Flycatchers in my harvested study site were never found in seed-tree stands of canopyheight and even-aged larch (Robertson, personal observation), but there is no published information on the relative use of this silvicultural subtype by flycatchers to empirically verify this prediction.

It is important to note that selectively harvested forest has only been shown to act as an ecological trap relative to recently burned forest, and only at my study sites in northern Montana. It remains unclear for how long this trap might persist in time, whether trap habitat represents a significant portion of the breeding habitat available to this species, and whether the 
discrepancy in reproductive success between these two habitats is sufficient to help account for the alarming and dramatic long-term population declines in the species throughout most of its breeding range (Sauer et al. 2011). Even so, the mechanism by which selectively harvested forests are attractive because of their structure and more abundant arthropod food supply and despite their comparatively high nest predator abundance would seem likely to impact Olivesided Flycatchers throughout a broad portion of their breeding range. Moreover, this mechanism is sufficiently general that it could, and may already, create ecological traps for other early-successional and postfire specialist birds.

As a corollary, it has become clear that ecological restoration efforts are now one of the most common unintentional causes of ecological traps for wild animals (Robertson and Hutto 2007, Mänd et al. 2009, Hawlena et al. 2010, Severns 2011), many of which are already in population decline. For this reason, habitat management to eliminate ecological traps also has the potential to create new ecological traps for nontarget species. It appears that human activity that reshuffles proximally and ultimately important aspects of natural environments can be both the cause of, and cure for, ecological traps. This under-recognized fact should impose a strong sense of awe and caution on conservationists and wildlife managers. Independently of the potential to create traps, snag removal to reduce trap habitat attractiveness for Olive-sided Flycatchers will have negative impacts on other taxa; snag removal will reduce habitat availability for primary, e.g., woodpeckers, and secondary, e.g., bluebirds, cavity-nesting birds.

The increasing frequency at which ecological traps are being discovered by researchers suggests that the need for approaches to eliminate them and prevent their creation in the first place will grow as well. This study provides a practical approach toward identifying management options to eliminate traps by reducing their attractiveness. Forest managers should be strongly cautioned against the generic application of specific management recommendations made herein without confirming their relevance to other locations and careful consideration of the consequences to other taxa.

Responses to this article can be read online at: http://www.ace-eco.org/issues/responses.php/533

\section{Acknowledgments:}

The author was supported by a fellowship from the Smithsonian Institution's National Zoological Park, the family of George Didden, and the Friends of the National Zoo. Data was collected with cooperation from Glacier National Park, the Flathead National Forest, the Plum Creek Timber Company, and the Avian Science Center and the University of Montana.

\section{LITERATURE CITED}

Aho, T., M. Kuitunen, J. Suhonen, T. Hakkari, and A. Jäntti. 1997. Effects of male removal on female foraging behavior in the Eurasian treecreeper. Behavioral Ecology and Sociobiology 41:49-53. http://dx.doi.org/10.1007/s002650050362

Altman, B., and R. Sallabanks. 2000. Olive-sided Flycatcher (Contopus cooperi). In A. Poole and F. Gill, editors. Birds of North America. Number 502. Academy of Natural Science, Philadelphia, Pennsylvania, USA, and American Ornithologists Union, Washington, D.C., USA.

Dwernychuk, L. W., and D. A. Boag. 1972. Ducks nesting in association with gulls-an ecological trap? Canadian Journal of Zoology 50:559-563. http://dx.doi.org/10.1139/z72-076

Fletcher, R., Jr., J. Orrock, and B. A. Robertson. 2012. How the type of environmental change alters the consequences of ecological traps. Proceedings of the Royal Society of London Series B 279:2546-2552.

Hawlena, D., D. Saltz, Z. Abramsky, and A. Bouskila. 2010. Ecological trap for desert lizards caused by anthropogenic changes in habitat structure that favor predator activity. Conservation Biology 24:803-809. http://dx.doi.org/10.1111/ j.1523-1739.2010.01477.x

Hedrick, A. V., and E. J. Temeles. 1989. The evolution of sexual dimorphism in animals: hypotheses and tests. Trends in Ecology and Evolution 4:136-138. http://dx.doi. org/10.1016/0169-5347(89)90212-7

Horvath, G., G. Kriska, P. Malik, and B. A. Robertson. 2009. Polarized light pollution: a new kind of ecological photopollution. Frontiers in Ecology and the Environment 7:317-325. http://dx.doi.org/10.1890/080129

Hutto, R. L. 1995. Composition of bird communities following stand-replacement fires in northern Rocky Mountain (U.S.A.) conifer forests. Conservation Biology 9:1041-1058. http://dx. doi.org/10.1046/j.1523-1739.1995.9051033.x-i1

Hutto, R. L., and J. S. Young. 1999. Habitat relationships of landbirds in the Northern Region. U.S. Forest Service. General Technical Report RMRS-GTR-32. Forest Service, Rocky Mountain Research Station, Ogden, Utah, USA.

Kokko, H., and W. J. Sutherland. 2001. Ecological traps in changing environments: ecological and evolutionary consequences of a behaviourally mediated Allee effect. Evolutionary Ecology Research 3:537-551.

Mänd, R., A. Leivits, M. Leivits, and N. L. Rodenhouse. 2009. Provision of nestboxes raises the breeding density of Great Tits Parus major equally in coniferous and deciduous woodland. Ibis 151:487-492. http://dx.doi.org/10.1111/ j.1474-919X.2009.00929.x

Meehan, T. D., and T. L. George. 2003. Short term effects of moderate- to high-severity wildfire on a disturbance- 
dependent flycatcher in northwest California. Auk 120:1102-1113.

Pechacek, P. 2006. Foraging behavior of Eurasian Three-toed Woodpeckers (Picoides tridactylus alpinus) in relation to sex and season in Germany. Auk 123:235-246. http://dx.doi. org/10.1642/0004-8038(2006)123[0235:FBOETW]2.0.CO;2

Powell, L. L., T. P. Hodgman, W. E. Glanz, J. D. Osenton, and C . M. Fisher. 2010. Nest-site selection and nest survival of the Rusty Blackbird: does timber management adjacent to wetlands create ecological traps? Condor 112:800-809. http:// dx.doi.org/10.1525/cond.2010.100152

Randler, C., S. Pentzold, and C. Teichmann. 2010. Weather conditions and sexual differences affect the foraging behavior of the insectivorous Cyprus Wheatear, Oenanthe cypriaca (Aves: Passeriformes: Muscicapidae). Vertebrate Zoology 60:175-181.

Robertson, B. A., and R. L. Hutto. 2006. A framework for understanding ecological traps and an evaluation of existing evidence. Ecology 87:1075-1085. http://dx.doi.org/10.1890/0012-9658 (2006)87[1075:AFFUET]2.0.CO;2

Robertson, B. A., and R. L. Hutto. 2007. Is selectively harvested forest an ecological trap for Olive-sided Flycatchers? Condor 109:109-121. http://dx.doi. org/10.1650/0010-5422(2007)109[109:ISHFAE]2.0.CO;2

Rodeward, A. D., D. P. Shustack, and T. M. Jones. 2011. Dynamic selective environments and evolutionary traps in human-dominated environments. Ecology 92:1781-1788. http://dx.doi.org/10.1890/11-0022.1

Rosenberg, K. V., and M. G. Raphael. 1986. Effects of forest fragmentation on vertebrates in Douglas-fir forests. Pages 263-272 in J. Verner, M. Morrison, and C. J. Ralph, editors. Modeling habitat relationships of terrestrial vertebrates. University of Wisconsin Press, Madison, Wisconsin, USA.

Sauer, J. R., J. E. Hines, J. E. Fallon, K. L. Pardieck, D. J. Ziolkowski, Jr., and W. A. Link. 2011. The North American Breeding Bird Survey, Results and Analysis 1966 - 2010. Version 12.07.2011 USGS Patuxent Wildlife Research Center, Laurel, Maryland, USA.

Schlaepfer, M. A., M. C. Runge, and P. W. Sherman. 2002. Ecological and evolutionary traps. Trends in Ecology and Evolution 17:474-480. http://dx.doi.org/10.1016/S0169-5347 (02)02580-6

Severns, P. M. 2011. Habitat restoration facilitates an ecological trap for a locally rare, wetland-restricted butterfly. Insect Conservation and Diversity 4:184-191. http://dx.doi. org/10.1111/j.1752-4598.2010.00120.x

SPSS. 2011. SPSS Version 19 for Windows. SPSS, Chicago, Illinois, USA.
Wright, J. M. 1997.Olive-sided Flycatchers in central Alaska, 1994-1996. Final Report Project SE-3-4. Alaska Department of Fish and Game. Federal Aid in Wildlife Restoration. Juneau, Alaska, USA. 